DEMOGRAPHIC RESEARCH

VOLUME 39, ARTICLE 26, PAGES 719-752

PUBLISHED 5 OCTOBER 2018

https://www.demographic-research.org/Volumes/Vol39/26/

DOI: 10.4054/DemRes.2018.39.26

Research Article

\title{
Multigenerational socioeconomic attainments and mortality among older men: An adjacent generations approach
}

Joseph Wolfe

Shawn Bauldry

Melissa Hardy

\section{Eliza K. Pavalko}

(C) 2018 Wolfe, Bauldry, Hardy \& Pavalko.

This open-access work is published under the terms of the Creative Commons Attribution 3.0 Germany (CC BY 3.0 DE), which permits use, reproduction, and distribution in any medium, provided the original author(s) and source are given credit.

See https://creativecommons.org/licenses/by/3.0/de/legalcode. 


\section{Contents}

$\begin{array}{lll}1 & \text { Introduction } & 720\end{array}$

$2 \quad$ Background 721

2.1 Multigenerational processes of status attainment and health 721

2.2 The long arm, personal attainment, and social foreground 722

$2.3 \quad$ Measuring socioeconomic attainment across the $20^{\text {th }}$ century $\quad 724$

$\begin{array}{lll}2.4 & \text { Fatherhood and mortality } & 727\end{array}$

$\begin{array}{lll}2.5 & \text { Wealth } & 728\end{array}$

3 Data, measures, and methods $\quad 728$

$\begin{array}{lll}3.1 & \text { Data } & 728\end{array}$

$\begin{array}{lll}3.2 & \text { Measurement } & 730\end{array}$

$\begin{array}{lll}3.3 & \text { Analytic strategy } & 733\end{array}$

$4 \quad$ Results $\quad 734$

$\begin{array}{lll}5 & \text { Conclusion and discussion } & 740\end{array}$

$\begin{array}{ll}\text { References } & 744\end{array}$ 


\title{
Multigenerational socioeconomic attainments and mortality among older men: An adjacent generations approach
}

\author{
Joseph Wolfe ${ }^{1}$ \\ Shawn Bauldry ${ }^{2}$ \\ Melissa Hardy ${ }^{3}$ \\ Eliza K. Pavalko ${ }^{4}$
}

\begin{abstract}
BACKGROUND

Recent work in stratification and demography argues for the importance of multiple familial generations in status attainment and other transmission processes. Health disparities research in this area generally assumes that the rewards of attainment are paid forward across generations, meaning grandparent and parent achievements give children a health advantage. However, an emerging literature suggests that mortality risk in old age may be more closely related to the attainments of parents and adult children.
\end{abstract}

\section{OBJECTIVE}

We develop a new approach to understanding family attainments and mortality in later life and test the multigenerational structure of health disparities suggested by the long arm, personal attainment, and social foreground perspectives.

\section{METHODS}

The analysis uses nearly complete mortality data from the National Longitudinal Survey of Older Men, a representative sample of US men aged 45 to 59 in 1966.

\section{RESULTS}

We find that older men with parents who farmed had a median age of death that was 1.3 years higher than those who had parents with manual occupations, and men with adult

\footnotetext{
${ }^{1}$ University of Alabama at Birmingham (UAB), USA. Email: jdwolfe@uab.edu.

${ }^{2}$ Purdue University, West Lafayette, Indiana, USA.

${ }^{3}$ Pennsylvania State University, USA.

${ }^{4}$ Indiana University, Bloomington, Indiana, USA.
} 
children who had 16 or more years of schooling had a median age of death almost 2 years higher than those with children with 12 or fewer years of schooling.

\section{CONCLUSIONS}

We find evidence of a three-generation model in which parent occupation, personal wealth, and adult child attainments are independently associated with older men's mortality.

\section{CONTRIBUTION}

These findings highlight the relevance of adjacent generations for health and mortality in later life and the importance of historical context for accurately measuring socioeconomic attainments in different generations and cohorts.

\section{Introduction}

Recent papers in stratification and demography argue for the relevance of multiple familial generations in both status attainment and health processes (Friedman and Mare 2014; Mare 2011, 2014). In response, a growing body of research provides evidence of a three-generation model in which both grandparent (G1) and parent (G2) attainments are associated with children's (G3) socioeconomic and health outcomes (e.g., Chan and Boliver 2013; Jæger 2012; Lê-Scherban et al. 2014). These studies move beyond twogeneration explanations that emphasize the importance of parent characteristics for individual outcomes, but regardless of the number of generations, these models assume an important temporal feature - the advantages or disadvantages of G1 flow forward to G2 and then, directly and indirectly, to G3. In this study we extend this threegeneration, or multigenerational, model by relaxing the assumption that advantages or disadvantages flow in only one direction. This adjustment allows for an association between G1, G2, and G3 achievements and G2 mortality. More specifically, we examine how survival among a cohort of older men is associated with the educational and occupational attainments of their parents and adult children.

Even as advances in health sciences, drug development, and medical technologies extend the length and quality of life for older populations in the United States, socioeconomic status remains a robust predictor of morbidity and mortality (Wallace 2012). Health disparities research examining mortality in adulthood generally focuses on individual attainment, but an emerging literature suggests that mortality risk among older adults is also linked to the education and occupation of parents and adult children (Friedman and Mare 2014; Pudrovska 2014; Torssander 2013). These findings suggest that adjacent generations (one's parents and adult children), rather than successive 
generations (one's parents and grandparents), offer health-related resources in old age. Nevertheless, this study is motivated by the fact that we know little about the extent to which multigenerational attainments are related to mortality in later adulthood, and prior research has yet to empirically test whether parent (G1), personal (G2), and adult child (G3) socioeconomic attainments are independently related to G2 longevity.

To address this gap we use nearly complete information on mortality from the National Longitudinal Survey of Older Men (NLS-OM), a nationally representative sample of US men aged 45 to 59. Over the course of 13 survey rounds from 1966 to 1990, these men provided extensive biographical information about their educational, occupational, and economic attainments in addition to the educational and occupational attainments of their parents and adult children. Results from Gompertz proportional hazards models provide evidence of a three-generation model in which the attainments of adjacent generations are related to the mortality risk of older men. Our findings highlight the relevance of adjacent generations for mortality and the importance of considering life stage and historical context when studying health disparities.

\section{Background}

\subsection{Multigenerational processes of status attainment and health}

Educational and occupational attainment processes have been a longstanding focus of study for social scientists interested in the United States stratification system. Foundational studies in this area aimed to map the intergenerational transfers through which parents' attainments enabled or constrained their children's life chances (Blau and Duncan 1967; Sewell, Haller, and Ohlendorf 1970; Sewell, Haller, and Portes 1969). These studies and subsequent extensions generally supported a Markovian pattern of inheritance in which grandparent (G1) attainments only have an indirect influence on children (G3) through parent (G2) resources (e.g., Cherlin and Furstenberg 1992; Warren and Hauser 1997).

More recently, however, a number of stratification scholars call for a longer view of inequality, one in which three or more familial generations have a direct influence on G3 (Mare 2011, 2014; Pfeffer 2014; Solon 2014). In contrast to an intergenerational process, multigenerational models of attainment consider the possibility of a nonMarkovian pattern in which any number of social and cultural institutions allow for the direct influence of generation $t$ on multiple subsequent generations $t+1, t+2, \ldots, t+\mathrm{k}$. Chan and Boliver (2013), for example, examine three British cohorts and find that the odds of children entering the highest compared to the lowest occupational class is approximately doubled if their grandparents were also in the highest class. Likewise, 
with US data, Song and Mare (2017) find evidence that an initial advantage in educational attainment may benefit the education of as many as three subsequent generations.

With respect to health, a small but growing body of research also finds varying support for a similar model of multigenerational attainments in which grandparents' and parents' attainments are related to children's health in early life and adulthood (Huang et al. 2015; Kwok et al. 2013; Lê-Scherban et al. 2014). Like status attainment scholarship, these models of children's health assume that the rewards of attainment are paid forward across successive generations, meaning grandparent (G1) and parent (G2) achievements give children (G3) a health advantage. For health and mortality in later life, however, studies examining the long arm, personal attainment, and social foreground perspectives suggest that G2 health disparities in later life may instead involve the attainments of past (G1) and future (G3) generations.

\subsection{The long arm, personal attainment, and social foreground perspectives}

Research on the long arm of childhood social conditions suggests that parental attainments are related to one's mortality risk in later life by way of both biological and social mechanisms (Haas 2008; Hayward and Gorman 2004). Parents' occupational and educational attainments generally reduce children's exposure to secondhand smoke, poor nutrition, dangerous housing materials (e.g., asbestos, mold, etc.), infectious disease, violence and crime, and interpersonal conflict (Cohen et al. 2010). On the one hand, these experiences may damage one's biological functioning to such an extent that, even though remaining latent for years, they damage health and mortality in later adulthood (Almond and Currie 2011). On the other hand, early life conditions may also impact health in later life by initiating an accumulation of social disadvantages that increasingly chip away at health over time (Hayward and Gorman 2004; Montez and Hayward 2014; Pudrovska and Anikputa 2014). Regardless of the specific pathways, this area of research provides evidence that parental attainment is likely linked to mortality in later life because of its influence on an array of childhood conditions.

The vast majority of health disparities research focuses on personal attainment in adulthood (Adler and Stewart 2010). Those with more educational attainment are generally able to secure better jobs with higher earnings and as a result are more likely to own homes free of carcinogens in safe neighborhoods, to receive medical insurance through their employers, and to eat healthier and more expensive diets (Evans and Kim 2010; Phelan, Link, and Tehranifar 2010). Beyond the benefits of higher earnings, human capital theories also argue that educational attainment helps develop cognitive (e.g., math skills and reading comprehension) and noncognitive (e.g., conscientiousness 
and a sense of mastery) resources that provide lifelong advantages with respect to avoiding and treating potentially deadly health problems (Pampel, Krueger, and Denney 2010; Ross and Mirowsky 2010).

Later adulthood and old age research within the social foreground perspective - a more recent development in demographic research - finds that the attainment of adult children may also contribute to an individual's health and wellbeing (Torssander 2013). The central argument of this growing literature is that children who attain more can use the resources at their disposal to improve the quality and length of their parents' lives. Research has currently identified relationships between adult children's SES and a range of health outcomes, including functional limitations, self-rated health, and mortality, using samples from multiple countries (Friedman and Mare 2014; Torssander 2013, 2014; Yahirun, Sheehan, and Hayward 2016; Zimmer, Hanson, and Smith 2016). Beyond the financial assistance high-attaining children can provide to elderly parents, the association between offspring's education and parents' mortality may also reflect direct care and health spillover (Friedman and Mare 2014). Children often provide direct care for their parents by assisting with medications, taking them to medical appointments, and helping with daily tasks (Pavalko and Wolfe 2016b). Health spillover suggests that adult children's socioeconomic attainments are accompanied by healthier lifestyles, which have a positive influence on parents' health behaviors. Thus, the socioeconomic attainments of children appear to provide parents with health-related resources that they would not otherwise have in later life.

Instead of competing explanations, we regard the long arm, personal attainment, and social foreground perspectives as components of a multigenerational process that unfolds as individuals age. In this process the socioeconomic attainments of the familial generations that surround a focal generation - what we refer to as adjacent generations - are key indicators of the resources available to individuals in older populations. In Figure 1 we provide a visualization of this conceptual model of mortality. Each shaded panel of Figure 1 represents a broad segment of the life course (i.e., childhood, adulthood, and old age) for a focal generation, G2. Within each life stage of G2, we show the theorized links between the attainment of each generation and the mortality risk of G2. In childhood the mortality risk of G2 is associated with parent attainment, in adulthood G2 mortality risk is associated with both parent and personal attainment, and in old age G2 mortality risk is associated with parent, personal, and adult child attainments. The dotted lines denote the multigenerational model of mortality that we consider in the analysis. Thus, a key contribution of this paper is that it considers the full multigenerational structure of health disparities suggested by the long arm, personal attainment, and social foreground perspectives. 
Figure 1: Conceptual model of multigenerational attainments and mortality across the life course of a focal generation

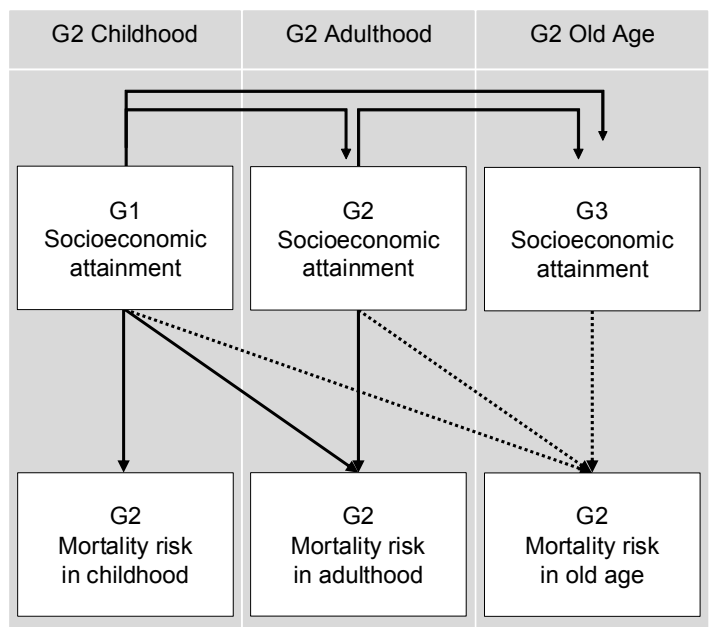

Notes: $\mathrm{G} 2$ denotes the focal generation, G1 denotes the parents of G2, and G3 denotes the adult children of G2. Our analysis only considers mortality risk in old age (dotted lines).

\subsection{Measuring socioeconomic attainment across the $20^{\text {th }}$ century}

Although Figure 1 provides a conceptual foundation for our model, it does not provide explicit guidance on the operationalization of socioeconomic attainment, which is complicated by the era of rapid social change in which the NLS-OM participants lived. They were born between 1906 and 1921, so they experienced the expansion of mass education, the Great Depression, and World War II. These historic events fundamentally shaped not only the biographies of these men but also the attainment process through which status was achieved in the United States. We discuss the implications of these social changes for operationalizing the socioeconomic attainments of G1, G2, and G3 in more detail below.

Health disparities research often focuses on education because of its current centrality to human capital development and labor market outcomes (Hout 2012; Hummer and Lariscy 2011), but in the earlier half of the $20^{\text {th }}$ century, life chances were relatively independent of education. For the parents of the NLS-OM, who came of age before secondary public schools were widely available in the United States, having less than a high school education was common, while a college degree was rare (Goldin 2003; Goldin and Katz 1999). The labor market in the late 1800s and early 1900s was 
substantially different to that encountered by the NLS-OM and their children. Agriculture and skilled labor accounted for the largest portion of the economy and required little formal schooling at the time. Consequently, for most of the parents of the NLS-OM an extended period of schooling was unnecessary, especially for those who were expected to help with a family business or farm.

While occupations shared general similarities across the $20^{\text {th }}$ century - e.g., whitecollar occupations were generally better with respect to pay, autonomy, and safe working environments than manual labor - owning and managing a farm was a much more prominent and profitable occupation early in the $20^{\text {th }}$ century when the NLS-OM were children (Alston et al. 2010). World War I began in 1914, and American famers filled the void created in global markets by fighting in Europe (Kennedy 1999). The farm population soon peaked in 1916 at approximately 33 million, over a third of the US population (Alston et al. 2010). Related to this, early stratification scholarship often discussed farming as a notable niche in the United States occupational structure and viewed rural communities as particularly interesting areas of study with respect to intergenerational attainment processes (Sewell 1964; Sewell, Haller, and Ohlendorf 1970; Sewell, Haller, and Portes 1969).

After WWI ended in 1918 global markets began to recover, and American farmers found themselves with a surplus of goods. Their crops flooded the market and caused a precipitous drop in prices (Kennedy 1999; Watkins 2000). As farms increasingly struggled to stay afloat financially, many families migrated to urban areas with opportunities in the growing manufacturing and mechanical industries. By 1920 American factories had surpassed agriculture as the largest category of employment, and as the financial viability of farming declined, industrial workers saw an almost $25 \%$ increase in real wages (Kennedy 1999). The average American laborer in this period worked twelve-hour days without a two-day weekend, paid vacation, job security, or any prospect of retirement. The living conditions of poor manual workers and their families were often dire as well. The health inequalities linked to areas of concentrated poverty in cities like Chicago and New York in the early 1900s were noted in some of the earliest works on urban life and health in the United States (Faris and Dunham 1939; Hollingshead and Redlich 1958). Thus, although farming families lived difficult lives due to the nature of their labor and the unpredictability of crop production, they avoided the pollution of urban areas in an era before the US Environmental Protection Agency (EPA) and other basic environmental regulations.

In 1929 the NLS-OM were entering early adolescence and adulthood as the United States was entering the Great Depression. Within four years the gross national product fell by $50 \%$ and business investment dropped by almost $90 \%$ (Kennedy 1999). Farmers were not spared. Their incomes dropped by over 60\% between 1929 and 1932 . Nevertheless, owning a farm indicated a degree of social and economic stability in an 
otherwise chaotic time. Farming families were also able to grow their own food when malnutrition was common (Watkins 2000) and generally lived in small communities of family and friends that could offer support in times of financial or emotional need (Elder and Conger 2000). Although white-collar and skilled laborers generally enjoyed higher incomes than farmers, they were also more likely to experience longer periods of unemployment, job insecurity, and geographic mobility while seeking employment.

During the lifetimes of the NLS-OM, educational opportunities and the monetary return of academic credentials began increasing due to the rise of a new US economy that involved a greater use of science in industry (Goldin 2003; Goldin and Katz 1999). Compared to more traditional approaches like apprenticeships, businesses began to realize that a general education gave white-collar professionals and their staff a flexible set of skills that improved productivity in an office setting. Likewise, a number of growing industries needed blue-collar workers with a basic understanding of math and chemical and electrical processes. This demand for educated labor, in combination with financial support from the federal government (e.g., the Serviceman's Readjustment Act of 1944, also known as the G.I. Bill, paid tuition and living expenses for WWII veterans attending high school, vocation/technical school, or college), set in motion the high school and higher education movements. In the earlier half of the $20^{\text {th }}$ century, student enrolment in two- and four-year institutions increased five-fold (Goldin and Katz 1999), and the economic return from an additional year of high school nearly doubled between 1915 and 1955 (Goldin 2003). The percentage of the population aged 25 to 29 years old with a bachelor's degree or higher went from around $10 \%$ in the 1950 s to around $20 \%$ in 1975 . By the end of the $20^{\text {th }}$ century a high school and college education was a necessary - but often insufficient - step in securing almost any mid- to high-earning job, and educational attainment is now more closely aligned than ever with social mobility (Hout 2012; Torche 2011).

As a result of the increased necessity of education for later occupational and economic attainments, a large body of research finds evidence that the education gap in mortality has continuously widened during the latter half of the $20^{\text {th }}$ century and the early $21^{\text {st }}$ century (Cutler et al. 2011; Masters, Hummer, and Powers 2012; Montez et al. 2011; Pappas et al. 1993). Pappas et al. (1993) find that educational inequalities in mortality risk increased by over $100 \%$ for men between 1960 and 1986. Meara, Richards, and Cutler (2008) find that gains in life expectancy between 1981 and 2000 only occurred among better-educated groups, and differences in life expectancy between those who had twelve or fewer years of schooling and those with thirteen or more years of schooling increased by 30\%. Miech et al. (2011) find that, if not for the growth of educational disparities since 1999, educational differences in longevity would currently be about $25 \%$ lower. Most of these studies focus on time periods when the NLS-OM were largely deceased or entering the twilight of their professional careers, 
but their findings still suggest that the association between education and mortality likely increased across the wide range of birth cohorts in the NLS-OM, 1906 to 1921. Furthermore, the continued growth in the returns on education for wealth and health since the 1980s suggests that cohort differences may also exist in the association between adult children's education and parents' survival.

In sum, historical forces across the $20^{\text {th }}$ century fundamentally reshaped the status attainment process that generations G1, G2, and G3 went through. Education grew in significance, becoming a key step in securing socioeconomic status, while farming steadily declined until it had nearly disappeared from the United States occupational structure by the 1970s. Thus, we operationalize the socioeconomic attainments of G1, G2, and G3 using both educational and occupational information, but we expect that these components are likely related to G2 mortality differently depending on the historical context of the generation.

\subsection{Fatherhood and mortality}

Our model of multigenerational attainments and mortality assumes offspring, but childless men may provide useful insights into the role of children in mortality disparities. In particular, comparing men with and without children can clarify whether fatherhood has a net positive or negative association with mortality risk and how the associations between family-level attainments and mortality may differ for men with and without access to the attainments of adult offspring. Fatherhood encompasses many responsibilities ranging from the financial to the emotional, and comes with a mix of risks and rewards (Umberson, Pudrovska, and Reczek 2010).

On one hand, there are several reasons to believe men with children may live longer than men without children. Those who remain childless do not have access to the additional resources of an entire familial generation in later life. Adult children often provide informal care for ill and disabled parents (Pavalko and Wolfe 2016a), and without children these men will have to rely on other institutional and familial resources when they enter old age and need living assistance. Without sufficient savings for later life, this could reduce the quality and length of the lives of childless men. Entering parenthood also tends to reduce unhealthy substance use and risk-taking (Wolfe 2009), and those who engage in, e.g., continuous heavy drinking, die at significantly younger ages (Rogers et al. 2015). This suggests that children promote important behavioral changes in young fathers and provide a network of informal caregivers for older fathers, giving those with children a net improvement in mortality risk.

On the other hand, a number of studies also suggest that men with children may

have a higher mortality risk than those without children. Familial obligations can 
increase stress levels, especially when they are related to or create financial strain (Conger, Conger, and Martin 2010). The daily expenses of children add up quickly, and although high-attaining children may provide health-related advantages, adult children who do not achieve may represent both an investment loss and a continued financial and emotional burden. Furthermore, men who remain childless may also be able to accumulate greater financial and material wealth, supplementing the lack of adult child attainments. In sum, remaining childless could provide a net advantage for mortality risk, especially when compared to fathers with low-attaining children.

\subsection{Wealth}

Our conceptual model of multigenerational attainment and mortality also assumes that the educational and occupational attainments of parents and adult children provide older men with health-related resources that they would not otherwise have, but prior research suggests that any relationships we observe could be the result of family wealth. Wealth reflects the socioeconomic attainments of prior generations and enables and constrains the life chances of future generations (Hällsten and Pfeffer 2017; Keister and Moller 2000; Prix and Pfeffer 2017). Long-term measures of economic attainment like wealth provide an approximation of personal traits that help amass wealth and protect health, e.g., intellectual abilities and noncognitive skills like discipline (Hällsten and Pfeffer 2017). Wealth also captures the quality of older men's living spaces and their ability to avoid financial distress (Evans 2004; Killewald, Pfeffer, and Schachner 2017; Lynch et al. 2000). Thus, our analysis considers total net worth to ensure that any associations we find between parent and adult child attainments and older men's mortality are not explained by family wealth.

\section{Data, measures, and methods}

\subsection{Data}

The analysis uses the National Longitudinal Survey of Older Men (NLS-OM), a prominent dataset among studies investigating mortality disparities in later life (e.g., 
Hayward and Gorman 2004; Moore and Hayward 1990; Warner and Hayward 2006). ${ }^{5}$ As compared with other nationally representative sources of data that include information on multiple generations, such as the Panel Study of Income Dynamics (PSID) and the Health and Retirement Survey (HRS), the NLS-OM collected nearly complete mortality information (as described below) and over twenty years of detailed biographical information on a nationally representative sample of 5,020 civilian, noninstitutionalized men between the ages of 45 and 59 in 1966. Information on mortality in the NLS-OM comes from two waves of data collection. For the first wave in 1990, Census obtained death certificates from state vital records departments or collected reports from widows or next of kin. The second wave of data collection occurred in 2009 by linking respondents to an age of death through the Demographic Survey Division (DSD) of the US Census Bureau (USCB) and the National Center on Health Statistics (NCHS). With further assistance from the Social Security Death Index, an age of death was assigned for 4,778 of the original 5,020 respondents. After dropping men who were in the "other" NLS racial category $(\mathrm{N}=82)$, the analysis sample of 4,938 men (4,138 with children and 800 without children) contains an age of death for $95 \%$ of the sample.

The analysis focuses on educational and occupational attainments, which are available for all three generations. Most measures of attainment have relatively low rates of missing data (roughly $15 \%$ or less), with the exception of parents' education and adult children's occupation. In the analysis sample, parents' education was not reported for $40 \%$ of respondents, which reflects the development of public education during the $20^{\text {th }}$ century. Schooling was still rare in much of the United States in the early $1900 \mathrm{~s}$. Of the $40 \%$ with missing data, $76 \%$ had parents who were either farmers or manual laborers. A formal education was most likely unavailable for many of their parents, and even when it was available, schooling was not necessary for occupational and economic attainment at this point in US history. Thus, these parents were assigned to the " 0 to 6 years" category of schooling. In supplemental analyses we also replicated statistical models with imputed data for parents' missing educational attainment information, and results were substantively identical to those that we present here. Another problematic variable is the occupational attainment of adult children, which is missing for $32 \%$ of the respondents. This high percentage of missing data is because the 1966 survey did not ask about the occupation of children who lived outside of the respondent's household.

\footnotetext{
${ }^{5}$ The data preparation, imputation, and analysis were conducted using Stata 15 (StataCorp 2015). All of the code necessary to replicate analysis, in addition to the online Appendix we discuss in the results, is maintained at a publicly available website (https://osf.io/8pc4q).
} 
Several precautions were taken to ensure that the handling of missing data and model specification did not meaningfully alter results. First, we used multiple imputation to construct 35 complete data sets, which is the recommended number for achieving stable parameter estimates and standard errors, given the fraction of missing information in the analysis sample (Graham, Olchowski, and Gilreath 2007). All descriptive statistics and model estimates were calculated using this imputed data. Diagnostic tests of the imputed data indicated that the values did not appreciably depart from the distributions of the variables in the original dataset (Eddings and Marchenko 2012). Second, the analysis was replicated after excluding parent educational attainment and adult child occupational attainments, the two variables that contain relatively large amounts of missing data. This supplemental analysis led to the same conclusions with respect to the association between multigenerational attainments and mortality. Third, to test the sensitivity of results for adult children, supplemental analysis also considered models that relied solely on adult child information from 1976. The association between adult child attainment and mortality remained significant and relatively large. Fourth, instead of assigning respondents to the " 0 to 6 years" category of parent education, the analysis was replicated using imputed data for respondents who did not report parent education. Once again, results from this analysis support the same substantive conclusions with respect to the association between multigenerational attainment and mortality.

\subsection{Measurement}

The age of respondents in 1966 serves as the time of entry into the risk set. Respondents ranged in age from 45 to 59 with an average age of 51. By 2012, 95\% of these men were deceased, with a median age of death of 76 . When possible, we operationalize socioeconomic attainment using educational, occupational, and economic attainments (Torssander and Erikson 2010; Wolfe 2015), but the NLS-OM only has indicators of respondents' economic attainment, e.g., income and assets. Thus, the analysis focuses on the educational and occupational attainments of all three generations and controls for respondents' wealth in the final statistical model.

Educational and occupational attainments: The analysis measures multigenerational attainments using education and occupation. Because the availability and necessity of education increased dramatically over the course of the $20^{\text {th }}$ century, each generation's education is coded to reflect their historical period. Parent education is measured as the years of education completed by either the respondents' mother or father (whoever had the highest education) when the respondent was age 15. Parent education is coded as (1) 0 to 6 years, (2) 7 to 11 years, and (3) 12 or more years 
because they completed far fewer years of schooling than other generations (see Table 1). For example, only $14 \%$ received 12 or more years of schooling, and although this seems extremely low it is similar to other estimates of secondary-school graduation during the early 1900s (Goldin 2003). Respondent education is measured as (1) 0 to 11 years, (2) 12 years, and (3) 13 or more years. Although the amount of schooling among respondents is greater than that of their parents, it is still low by today's standards, with only $21 \%$ attaining 12 years of schooling and only $14 \%$ attaining 13 or more years.

Table 1: Means or proportions of analysis variables for older men $(\mathrm{N}=\mathbf{4 , 9 3 8 )}$

\begin{tabular}{|c|c|c|c|c|}
\hline & Mean or proportion & S.D. & Min & Max \\
\hline Age in 1966 & 51.52 & 4.26 & 45 & 59 \\
\hline Age of death & 76 & & 48 & 90 \\
\hline Deceased by 2012 & 0.95 & & 0 & 1 \\
\hline Parent education & & & 0 & 2 \\
\hline 0 to 6 years & 0.60 & & & \\
\hline 7 to 11 years & 0.26 & & & \\
\hline 12 or more years & 0.14 & & & \\
\hline Parent occupation & & & 0 & 3 \\
\hline Manual & 0.30 & & & \\
\hline Skilled & 0.17 & & & \\
\hline White-collar & 0.14 & & & \\
\hline Farming & 0.39 & & & \\
\hline Education & & & 0 & 2 \\
\hline 0 to 11 years & 0.65 & & & \\
\hline 12 years & 0.21 & & & \\
\hline 13 or more years & 0.14 & & & \\
\hline Occupation & & & 0 & 3 \\
\hline Manual & 0.42 & & & \\
\hline Skilled & 0.31 & & & \\
\hline White-collar & 0.18 & & & \\
\hline Farming & 0.09 & & & \\
\hline Adult child education & & & 0 & 2 \\
\hline 0 to 12 years & 0.49 & & & \\
\hline 13 to 15 years & 0.18 & & & \\
\hline 16 or more years & 0.33 & & & \\
\hline Adult child occupation & & & 0 & 2 \\
\hline Manual & 0.21 & & & \\
\hline Skilled & 0.34 & & & \\
\hline White-collar & 0.45 & & & \\
\hline Log total net worth & 9.93 & 4.05 & 0 & 15.84 \\
\hline Divorced, never married, or widowed & 0.21 & & 0 & 1 \\
\hline Lived with both parents at 15 & 0.72 & & 0 & 1 \\
\hline Number of children & 2.79 & 2.45 & 0 & 16 \\
\hline Number of sons & 1.19 & 1.27 & 0 & 5 \\
\hline Black & 0.29 & & 0 & 1 \\
\hline Immigrant parent(s) & 0.23 & & 0 & 1 \\
\hline
\end{tabular}

Notes: The median, rather than the mean, age of death is calculated from deceased respondents. Adult child education and occupation exclude men without children $(\mathrm{N}=800)$. 
Adult child education is measured as (0) 0 to 12 years, (1) 13 to 15 years, and (2) 16 or more years. Following Friedman and Mare (2014), only the attainments of adult children aged 25 and older are considered. The coding of educational categories reflects a major upswing in educational attainment in the United States. For example, over a third of the men with children have at least one child with 16 or more years of schooling. The construction of parent and respondent attainment is straightforward, but there are a number of ways to summarize the attainments of multiple children. The analysis currently uses the highest level of education and the most prestigious occupation among children (Torssander 2014), but supplemental analyses also considered the mean and median education of children. Other measures of adult children's attainment provided the same conclusions. Finally, to adjust for men without children we include a mutually exclusive category for childless men $(\mathrm{N}=800)$. We replicated the analysis after dropping men without children (see Table A-3 and Figure A-1 in the online Appendix) and found further support for the conclusions we discuss here.

Occupational attainment is measured as a categorical variable that includes categories for manual (private household, service, operators, transportation, or laborers), farming (farmers and farm managers), skilled (technical and related support, sales, administrative support, protective services, or the military), and white-collar (managerial or professional specialty) occupations. Most respondents (39\%) reported that the head of their household was a farmer, followed by manual, skilled, and whitecollar workers. Almost $10 \%$ of respondents also reported farming, but the majority of respondents were manual or skilled workers. Adult child occupation is measured as a similar set of binaries but does not include a category for farming. Only 98 respondents reported having a child whose primary occupation was farming. Of these 98 respondents, 30 had other children with skilled occupations, and 49 had children with white-collar occupations. This left only 19 respondents whose highest-attaining child with respect to occupation was a farmer or farm manager. Thus, adult child occupational attainment for these 19 respondents is set to manual.

Wealth: The final model adjusts for respondents' midlife economic attainment, which is operationalized as the log of respondent's average net worth in 1966, 1969, 1971, and 1976. To calculate net worth, the NLS collects information on the market value of homes, apartments, and other real estate; the amount the family had in money assets; the value of common stock and bonds; the amount in investments; the value of estates and trusts; and the value of vehicles. A family's net worth is measured as the sum of these items minus debt.

Sociodemographic controls: In addition to measures of multigenerational attainments, every statistical model includes measures of race, parents' nativity, marital status, family structure, and adult child characteristics. Race is measured as a binary 
variable denoting whether respondents are white or black. Parents' nativity is measured as a binary indicating those who have at least one foreign-born parent. Family structure is measured as a binary denoting those who lived with both biological parents at 15 versus all other family structures. Marital history is measured as a binary indicating those who were not continuously married. Finally, we control for the number of children and sons that older men reported.

\subsection{Analytic strategy}

The analysis uses Gompertz proportional hazards models with age of entry defined by the respondent's age at the 1966 survey and age of death (or age in 2012 for those still living) measured in years. Gompertz models allow for an increasing hazard rate over time, as one would expect with the risk of death, and are commonly used when modeling mortality in developed countries (Preston, Heuveline, and Guillot 2001). Parameter estimates were averaged across the 35 complete data sets with standard errors obtained via Rubin's rules. Supplemental analyses (available online at https://osf.io/8pc4q) were also conducted using Cox models that do not assume a specific distribution, and the same substantive pattern of results emerged (see Table A-5 in the online Appendix). Both the Gompertz and Cox models are members of the proportional hazard family of survival models, which assume estimated hazard ratios are proportional over time. The proportional hazard assumption was tested using Schoenfeld residuals and found to hold for most variables (Kalbfleisch and Prentice 2011). Auxiliary analyses relaxed the proportional hazard assumption for problematic variables and found the same conclusions regarding multigenerational attainments and mortality.

We begin the analysis by examining the baseline associations between mortality and three sets of variables related to G1, G2, and G3 attainments in order to assess their net associations with G2 mortality. ${ }^{6}$ Because the sample includes a wide range of birth cohorts during rapid social change (see our discussion on measuring socioeconomic attainment across the $20^{\text {th }}$ century), we then compare two birth cohorts, an older one born 1906-1913 $(\mathrm{N}=2,321)$ and a younger one born 1914-1921 $(\mathrm{N}=2,617)$, to test the sensitivity of results and to elaborate on findings. Finally, to examine how the associations between family-level attainments and mortality may differ for men with

\footnotetext{
${ }^{6}$ We considered models stratified by race in supplemental analyses to check the consistency of results across racial groups (see Tables A-6 and A-7 in the online Appendix). These analyses led to the same general conclusions we present here.
} 
and without children, we compare childless men to fathers of children with varying levels of attainment.

\section{Results}

Table 2 reports hazard ratios from Gompertz proportional hazards models and contains several notable results. First, with respect to parents' attainment, farming has a robust association with older men's mortality, reducing risk by $13 \%$ in every model $(p<.001)$. Second, although personal attainment is robustly related to mortality in Model 2, adult child attainment in Model 4 and wealth in Model 5 notably attenuate the associations between older men's education and occupation and their mortality risk. Third, adult child attainments are significantly related to reductions in mortality risk, even after controlling for parent and personal attainments. In Model 5, for example, having a child with 16 or more years of schooling is related to a $17 \%$ reduction in mortality risk $(95 \%$ $\mathrm{CI}=.75, .92)$.

Table 2: Exponentiated parameter estimates (hazard ratios) from Gompertz proportional hazards models for older men $(\mathrm{N}=4,938)$

\begin{tabular}{|c|c|c|c|c|c|}
\hline & Model 1 & Model 2 & Model 3 & Model 4 & Model 5 \\
\hline \multicolumn{6}{|c|}{ Parent education (ref. 0 to 6 ) } \\
\hline \multirow[t]{2}{*}{7 to 11 years } & 0.95 & & & 1.01 & 1.03 \\
\hline & $(0.04)$ & & & $(0.04)$ & $(0.04)$ \\
\hline \multirow[t]{2}{*}{12 or more years } & $0.88^{*}$ & & & 1.00 & 1.01 \\
\hline & $(0.05)$ & & & $(0.06)$ & $(0.06)$ \\
\hline \multicolumn{6}{|c|}{ Parent occupation (ref. manual) } \\
\hline \multirow[t]{2}{*}{ Skilled labor } & 0.96 & & & 1.00 & 1.01 \\
\hline & $(0.05)$ & & & $(0.05)$ & $(0.05)$ \\
\hline \multirow[t]{2}{*}{ White-collar } & 0.90 & & & 0.98 & 0.99 \\
\hline & $(0.05)$ & & & $(0.06)$ & $(0.06)$ \\
\hline \multirow[t]{2}{*}{ Farming } & $0.87^{\star \star \star}$ & & & $0.87^{\star \star *}$ & $0.87^{\star \star \star}$ \\
\hline & $(0.03)$ & & & $(0.03)$ & $(0.04)$ \\
\hline \multicolumn{6}{|c|}{ Personal education (ref. 0 to 11 ) } \\
\hline \multirow[t]{2}{*}{12 years } & & $0.91^{*}$ & & 0.94 & 0.95 \\
\hline & & $(0.04)$ & & $(0.04)$ & $(0.04)$ \\
\hline \multirow[t]{2}{*}{13 or more years } & & $0.82^{\star \star \star}$ & & $0.87^{*}$ & $0.89^{*}$ \\
\hline & & $(0.04)$ & & $(0.05)$ & $(0.05)$ \\
\hline \multicolumn{6}{|c|}{ Personal occupation (ref. manual) } \\
\hline \multirow[t]{2}{*}{ Skilled labor } & & $0.88^{* * *}$ & & $0.91^{* *}$ & 0.94 \\
\hline & & $(0.03)$ & & $(0.03)$ & $(0.04)$ \\
\hline \multirow[t]{2}{*}{ White-collar } & & $0.82^{\star \star *}$ & & $0.86^{\star \star}$ & 0.91 \\
\hline & & $(0.04)$ & & $(0.05)$ & $(0.05)$ \\
\hline \multirow[t]{2}{*}{ Farming } & & $0.79^{* * *}$ & & $0.84^{\star *}$ & 0.92 \\
\hline & & $(0.04)$ & & $(0.05)$ & $(0.05)$ \\
\hline
\end{tabular}


Table 2: (Continued)

\begin{tabular}{|c|c|c|c|c|c|}
\hline & Model 1 & Model 2 & Model 3 & Model 4 & Model 5 \\
\hline \multicolumn{6}{|l|}{ Child education (ref. 0 to 12 years) } \\
\hline \multirow[t]{2}{*}{13 to 15 years } & & & $0.79^{\star \star \star}$ & $0.82^{\star \star \star}$ & $0.85^{\star \star}$ \\
\hline & & & $(0.04)$ & $(0.04)$ & $(0.05)$ \\
\hline \multirow[t]{2}{*}{16 or more } & & & $0.76^{\star * *}$ & $0.79^{\star \star *}$ & $0.83^{* * *}$ \\
\hline & & & $(0.04)$ & $(0.04)$ & $(0.04)$ \\
\hline \multirow[t]{2}{*}{ No children } & & & $0.83^{\star \star}$ & $0.85^{\star}$ & 0.89 \\
\hline & & & $(0.05)$ & $(0.06)$ & $(0.06)$ \\
\hline \multicolumn{6}{|l|}{ Child occupation (ref. manual) } \\
\hline \multirow[t]{2}{*}{ Skilled labor } & & & $0.87^{*}$ & $0.87^{*}$ & 0.90 \\
\hline & & & $(0.06)$ & $(0.06)$ & $(0.06)$ \\
\hline \multirow[t]{2}{*}{ White-collar } & & & $0.80^{* \star *}$ & $0.80^{\star \star \star}$ & $0.83^{* *}$ \\
\hline & & & $(0.05)$ & $(0.05)$ & $(0.05)$ \\
\hline \multirow[t]{2}{*}{ Log total net worth } & & & & & $0.96^{* * *}$ \\
\hline & & & & & $(0.00)$ \\
\hline \multirow[t]{2}{*}{ Divorced, never married, or widowed } & $1.15^{\star \star \star}$ & $1.14^{\star \star *}$ & $1.09^{*}$ & $1.08^{*}$ & 1.01 \\
\hline & $(0.04)$ & $(0.04)$ & $(0.04)$ & $(0.04)$ & $(0.04)$ \\
\hline \multirow[t]{2}{*}{ Lived with both parents at 15} & 0.97 & 0.98 & 0.97 & 0.99 & 1.01 \\
\hline & $(0.03)$ & $(0.03)$ & $(0.03)$ & $(0.03)$ & $(0.03)$ \\
\hline \multirow[t]{2}{*}{ Number of children } & $1.03^{* * *}$ & $1.03^{* * *}$ & $1.04^{\star \star *}$ & $1.04^{\star \star \star}$ & $1.04^{* * *}$ \\
\hline & $(0.01)$ & $(0.01)$ & $(0.01)$ & $(0.01)$ & $(0.01)$ \\
\hline \multirow[t]{2}{*}{ Number of sons } & $0.91^{\star \star *}$ & $0.91^{* * *}$ & $0.91^{\star \star \star}$ & $0.91^{\star \star \star}$ & $0.91^{* * *}$ \\
\hline & $(0.02)$ & $(0.02)$ & $(0.02)$ & $(0.02)$ & $(0.02)$ \\
\hline \multirow[t]{2}{*}{ Black } & $1.15^{\star \star *}$ & 1.05 & 1.07 & 1.01 & 0.93 \\
\hline & $(0.04)$ & $(0.04)$ & $(0.04)$ & $(0.04)$ & $(0.04)$ \\
\hline \multirow[t]{2}{*}{ Immigrant parents } & $0.86^{* * *}$ & $0.88^{* * *}$ & $0.90^{\star *}$ & $0.86^{\star * *}$ & $0.87^{* * *}$ \\
\hline & $(0.03)$ & $(0.03)$ & $(0.03)$ & $(0.03)$ & $(0.03)$ \\
\hline
\end{tabular}

Notes: Standard errors in parentheses. ${ }^{*} p \leq 0.05,{ }^{* *} p \leq 0.01,{ }^{* * *} p \leq 0.001$ (two-tailed tests). All models control for age in 1966.

To gain a better sense of the relative sizes of associations in Table 2, we calculate predicted median ages of death. Figure 2 displays the differences in the predicted median ages of death for covariates of interest. We selected categories to compare based on the significance and size of coefficients in Table 2. With respect to adjacent generations, we find that the median age of death for men who had parents who farmed is 1.35 years longer $(95 \% \mathrm{CI}=.56,2.14)$ than those who had parents with manual occupations, holding all other variables at their means. The median age of death for men who have adult children with 16 or more years of schooling is approximately 1.84 years longer $(95 \% \mathrm{CI}=.80,2.87)$ than men with low-attaining children. 
Figure 2: Differences in the estimated median age of death with $95 \%$ confidence intervals from Gompertz proportional hazards models

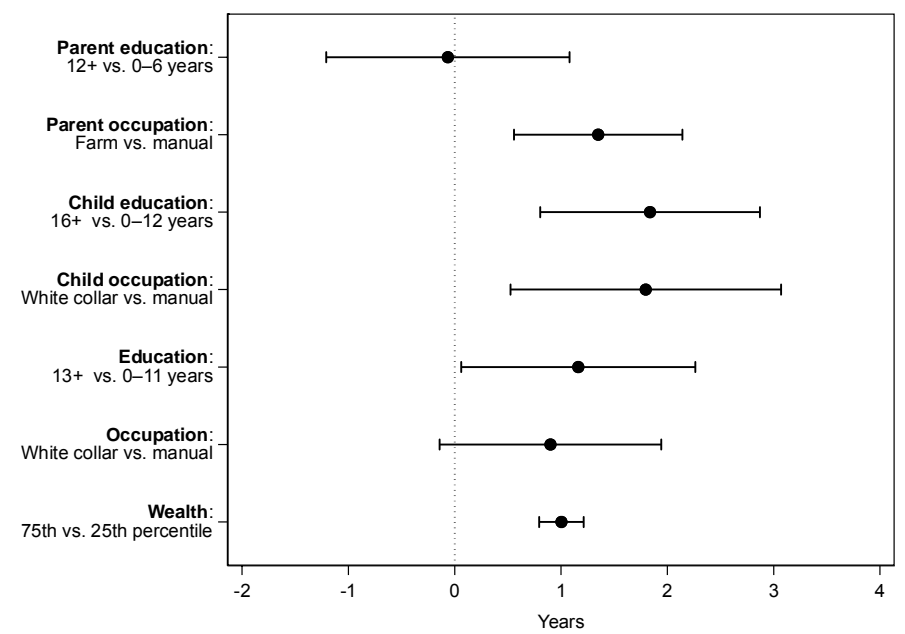

Notes: Postestimation values displayed in this figure are calculated from Model 5 in Table 2. Each point represents a difference in predicted median ages of death between, e.g., those who had parents who farmed versus those who had parents with manual occupations. Differences in the estimated median age of death are significant at the .05 level if their confidence intervals do not overlap 0 . All other covariates are held at their mean values.

In Table 3 we compare the 1906-1913 $(\mathrm{N}=2,321)$ and 1914-1921 $(\mathrm{N}=2,617)$ cohorts. For the 1914-1921 cohort, Models 1 through 5 all contain a significant association between the education of at least one generation and mortality, whereas the significance of the education-mortality association is less consistent across models for the older cohort. In supplemental analyses (see Table A-2 in the online Appendix), however, we only find statistically significant cohort differences in the associations between adult child attainment and mortality. More specifically, we find that adult child education has a larger association with survival for the younger cohort, whereas adult child occupation has a larger association with survival for the older cohort. 
Table 3: Exponentiated parameter estimates (hazard ratios) from Gompertz proportional hazards models by birth cohort (1906-1913 cohort $N=2,321 ; 1914-1921$ cohort $N=2,617$ )

\begin{tabular}{|c|c|c|c|c|c|c|c|c|c|c|}
\hline \multirow[b]{2}{*}{ Birth cohort } & \multicolumn{2}{|l|}{ Model 1} & \multicolumn{2}{|l|}{ Model 2} & \multicolumn{2}{|l|}{ Model 3} & \multicolumn{2}{|l|}{ Model 4} & \multicolumn{2}{|l|}{ Model 5} \\
\hline & $\begin{array}{l}1906- \\
1913\end{array}$ & $\begin{array}{l}1914- \\
1921\end{array}$ & $\begin{array}{l}1906- \\
1913\end{array}$ & $\begin{array}{l}1914- \\
1921\end{array}$ & $\begin{array}{l}1906- \\
1913\end{array}$ & $\begin{array}{l}1914- \\
1921\end{array}$ & $\begin{array}{l}1906- \\
1913\end{array}$ & $\begin{array}{l}1914- \\
1921\end{array}$ & $\begin{array}{l}1906- \\
1913\end{array}$ & $\begin{array}{l}1914- \\
1921\end{array}$ \\
\hline \multicolumn{11}{|l|}{ Parent education (ref. 0 to 6 ) } \\
\hline 7 to 11 years & $\begin{array}{c}0.99 \\
(0.06)\end{array}$ & $\begin{array}{c}0.92 \\
(0.05)\end{array}$ & & & & & $\begin{array}{c}1.08 \\
(0.07)\end{array}$ & $\begin{array}{c}0.98 \\
(0.05)\end{array}$ & $\begin{array}{c}1.09 \\
(0.07)\end{array}$ & $\begin{array}{c}1.00 \\
(0.05)\end{array}$ \\
\hline 12 or more years & $\begin{array}{c}0.90 \\
(0.07)\end{array}$ & $\begin{array}{c}0.86^{\star} \\
(0.06)\end{array}$ & & & & & $\begin{array}{c}1.00 \\
(0.08)\end{array}$ & $\begin{array}{c}0.99 \\
(0.08)\end{array}$ & $\begin{array}{c}1.02 \\
(0.09)\end{array}$ & $\begin{array}{c}0.99 \\
(0.08)\end{array}$ \\
\hline \multicolumn{11}{|l|}{ Parent occupation (ref. manual) } \\
\hline Skilled labor & $\begin{array}{c}0.94 \\
(0.07)\end{array}$ & $\begin{array}{c}0.97 \\
(0.07)\end{array}$ & & & & & $\begin{array}{c}0.96 \\
(0.07)\end{array}$ & $\begin{array}{c}1.03 \\
(0.07)\end{array}$ & $\begin{array}{c}0.98 \\
(0.07)\end{array}$ & $\begin{array}{c}1.04 \\
(0.07)\end{array}$ \\
\hline White-collar & $\begin{array}{c}0.88 \\
(0.07)\end{array}$ & $\begin{array}{c}0.91 \\
(0.07)\end{array}$ & & & & & $\begin{array}{c}0.96 \\
(0.08)\end{array}$ & $\begin{array}{c}1.00 \\
(0.08)\end{array}$ & $\begin{array}{c}0.97 \\
(0.08)\end{array}$ & $\begin{array}{c}1.02 \\
(0.08)\end{array}$ \\
\hline Farming & $\begin{array}{l}0.84^{* *} \\
(0.05)\end{array}$ & $\begin{array}{c}0.89^{*} \\
(0.05)\end{array}$ & & & & & $\begin{array}{c}0.87^{*} \\
(0.05)\end{array}$ & $\begin{array}{c}0.88^{*} \\
(0.05)\end{array}$ & $\begin{array}{c}0.87^{*} \\
(0.05)\end{array}$ & $\begin{array}{c}0.88^{*} \\
(0.05)\end{array}$ \\
\hline \multicolumn{11}{|l|}{ Education (ref. 0 to 11 ) } \\
\hline 12 years & & & $\begin{array}{c}0.89 \\
(0.06)\end{array}$ & $\begin{array}{c}0.91 \\
(0.05)\end{array}$ & & & $\begin{array}{c}0.90 \\
(0.06)\end{array}$ & $\begin{array}{c}0.96 \\
(0.05)\end{array}$ & $\begin{array}{c}0.92 \\
(0.06)\end{array}$ & $\begin{array}{c}0.98 \\
(0.05)\end{array}$ \\
\hline 13 or more years & & & $\begin{array}{c}0.87 \\
(0.07)\end{array}$ & $\begin{array}{l}0.78^{\star \star *} \\
(0.05)\end{array}$ & & & $\begin{array}{c}0.91 \\
(0.07)\end{array}$ & $\begin{array}{c}0.85^{\star} \\
(0.07)\end{array}$ & $\begin{array}{c}0.93 \\
(0.08)\end{array}$ & $\begin{array}{c}0.87 \\
(0.07)\end{array}$ \\
\hline \multicolumn{11}{|l|}{ Occupation (ref. manual) } \\
\hline Skilled labor & & & $\begin{array}{c}0.90^{*} \\
(0.05)\end{array}$ & $\begin{array}{l}0.85^{\star \star} \\
(0.04)\end{array}$ & & & $\begin{array}{c}0.94 \\
(0.05)\end{array}$ & $\begin{array}{c}0.88^{*} \\
(0.05)\end{array}$ & $\begin{array}{c}0.99 \\
(0.06)\end{array}$ & $\begin{array}{c}0.90 \\
(0.05)\end{array}$ \\
\hline White-collar & & & $\begin{array}{c}0.83^{*} \\
(0.06)\end{array}$ & $\begin{array}{l}0.81^{\star *} \\
(0.06)\end{array}$ & & & $\begin{array}{c}0.88 \\
(0.07)\end{array}$ & $\begin{array}{c}0.85^{\star} \\
(0.06)\end{array}$ & $\begin{array}{c}0.94 \\
(0.07)\end{array}$ & $\begin{array}{c}0.89 \\
(0.07)\end{array}$ \\
\hline Farming & & & $\begin{array}{c}0.81^{* *} \\
(0.06)\end{array}$ & $\begin{array}{l}0.77^{\star *} \\
(0.06)\end{array}$ & & & $\begin{array}{c}0.83^{*} \\
(0.07)\end{array}$ & $\begin{array}{c}0.86 \\
(0.07)\end{array}$ & $\begin{array}{c}0.92 \\
(0.07)\end{array}$ & $\begin{array}{c}0.93 \\
(0.08)\end{array}$ \\
\hline Child education (ref. 0 to 12 ) & & & & & & & & & & \\
\hline 13 to 15 years & & & & & $\begin{array}{c}0.87 \\
(0.06)\end{array}$ & $\begin{array}{l}0.73^{\star \star \star} \\
(0.05)\end{array}$ & $\begin{array}{c}0.88 \\
(0.07)\end{array}$ & $\begin{array}{l}0.76^{\star * *} \\
(0.06)\end{array}$ & $\begin{array}{c}0.92 \\
(0.07)\end{array}$ & $\begin{array}{l}0.80^{\star \star} \\
(0.06)\end{array}$ \\
\hline 16 or more & & & & & $\begin{array}{c}0.86^{*} \\
(0.06)\end{array}$ & $\begin{array}{l}0.68^{\text {** }} \\
(0.05)\end{array}$ & $\begin{array}{c}0.89 \\
(0.07)\end{array}$ & $\begin{array}{l}0.71^{\star \star *} \\
(0.05)\end{array}$ & $\begin{array}{c}0.95 \\
(0.07)\end{array}$ & $\begin{array}{l}0.75^{\star \star \star} \\
(0.05)\end{array}$ \\
\hline No children & & & & & $\begin{array}{c}0.81^{*} \\
(0.08)\end{array}$ & $\begin{array}{c}0.82^{*} \\
(0.08)\end{array}$ & $\begin{array}{c}0.83^{*} \\
(0.08)\end{array}$ & $\begin{array}{c}0.84 \\
(0.08)\end{array}$ & $\begin{array}{c}0.87 \\
(0.08)\end{array}$ & $\begin{array}{c}0.88 \\
(0.09)\end{array}$ \\
\hline Child occupation (ref. manual) & & & & & & & & & & \\
\hline Skilled labor & & & & & $\begin{array}{l}0.70^{\star \star} \\
(0.07)\end{array}$ & $\begin{array}{c}1.02 \\
(0.09)\end{array}$ & $\begin{array}{l}0.70^{\text {*** }} \\
(0.07)\end{array}$ & $\begin{array}{c}1.01 \\
(0.09)\end{array}$ & $\begin{array}{c}0.72^{* *} \\
(0.08)\end{array}$ & $\begin{array}{c}1.06 \\
(0.10)\end{array}$ \\
\hline White-collar & & & & & $\begin{array}{l}0.66^{\star \star *} \\
(0.06)\end{array}$ & $\begin{array}{c}0.92 \\
(0.08)\end{array}$ & $\begin{array}{l}0.65^{\star \star *} \\
(0.07)\end{array}$ & $\begin{array}{c}0.92 \\
(0.08)\end{array}$ & $\begin{array}{l}0.67^{* * *} \\
(0.07)\end{array}$ & $\begin{array}{c}0.97 \\
(0.09)\end{array}$ \\
\hline Log total net worth & & & & & & & & & $\begin{array}{l}0.96^{* * *} \\
(0.01)\end{array}$ & 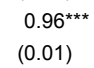 \\
\hline $\begin{array}{l}\text { Divorced, never married, or } \\
\text { widowed }\end{array}$ & $\begin{array}{l}1.12^{*} \\
(0.06)\end{array}$ & $\begin{array}{l}1.17^{* *} \\
(0.06)\end{array}$ & $\begin{array}{c}1.11 \\
(0.06)\end{array}$ & $\begin{array}{l}1.16^{\star *} \\
(0.06)\end{array}$ & $\begin{array}{c}1.05 \\
(0.06)\end{array}$ & $\begin{array}{r}1.13^{*} \\
(0.06)\end{array}$ & $\begin{array}{c}1.03 \\
(0.06)\end{array}$ & $\begin{array}{l}1.12^{*} \\
(0.06)\end{array}$ & $\begin{array}{c}0.95 \\
(0.06)\end{array}$ & $\begin{array}{c}1.05 \\
(0.06)\end{array}$ \\
\hline Lived with both parents at 15 & $\begin{array}{c}0.98 \\
(0.05)\end{array}$ & $\begin{array}{c}0.96 \\
(0.04)\end{array}$ & $\begin{array}{c}0.99 \\
(0.05)\end{array}$ & $\begin{array}{c}0.96 \\
(0.04)\end{array}$ & $\begin{array}{c}0.97 \\
(0.05)\end{array}$ & $\begin{array}{c}0.96 \\
(0.04)\end{array}$ & $\begin{array}{c}1.00 \\
(0.05)\end{array}$ & $\begin{array}{c}0.97 \\
(0.05)\end{array}$ & $\begin{array}{c}1.03 \\
(0.05)\end{array}$ & $\begin{array}{c}0.97 \\
(0.05)\end{array}$ \\
\hline
\end{tabular}


Wolfe et al.: Multigenerational socioeconomic attainments and mortality among older men

Table 3: (Continued)

\begin{tabular}{|c|c|c|c|c|c|c|c|c|c|c|}
\hline \multirow[b]{2}{*}{ Birth cohort } & \multicolumn{2}{|l|}{ Model 1} & \multicolumn{2}{|l|}{ Model 2} & \multicolumn{2}{|l|}{ Model 3} & \multicolumn{2}{|l|}{ Model 4} & \multicolumn{2}{|l|}{ Model 5} \\
\hline & $\begin{array}{l}1906- \\
1913\end{array}$ & $\begin{array}{l}1914- \\
1921\end{array}$ & $\begin{array}{l}1906- \\
1913\end{array}$ & $\begin{array}{l}1914- \\
1921\end{array}$ & $\begin{array}{l}1906- \\
1913\end{array}$ & $\begin{array}{l}1914- \\
1921\end{array}$ & $\begin{array}{l}1906- \\
1913\end{array}$ & $\begin{array}{l}1914- \\
1921\end{array}$ & $\begin{array}{l}1906- \\
1913\end{array}$ & $\begin{array}{l}1914- \\
1921\end{array}$ \\
\hline \multirow[t]{2}{*}{ Number of children } & $1.03^{*}$ & $1.04^{\star *}$ & $1.03^{*}$ & $1.03^{* *}$ & $1.05^{\star \star \star}$ & $1.03^{*}$ & $1.06^{\star \star \star}$ & $1.04^{*}$ & $1.05^{\star \star}$ & $1.03^{*}$ \\
\hline & $(0.01)$ & $(0.01)$ & $(0.01)$ & $(0.01)$ & $(0.01)$ & $(0.01)$ & $(0.02)$ & $(0.01)$ & $(0.02)$ & $(0.01)$ \\
\hline \multirow[t]{2}{*}{ Number of sons } & $0.90^{\star \star \star}$ & $0.92^{\star * *}$ & $0.89^{* * *}$ & $0.92^{* \star *}$ & $0.90^{\star * *}$ & $0.92^{* *}$ & $0.90^{\star \star \star}$ & $0.92^{* \star *}$ & $0.91^{* \star \star}$ & $0.92^{* *}$ \\
\hline & $(0.02)$ & $(0.02)$ & $(0.02)$ & $(0.02)$ & $(0.02)$ & $(0.02)$ & $(0.02)$ & $(0.02)$ & $(0.02)$ & $(0.02)$ \\
\hline \multirow[t]{2}{*}{ Black } & $1.21^{\star \star \star}$ & 1.09 & 1.10 & 0.99 & 1.10 & 1.03 & 1.05 & 0.96 & 0.95 & 0.89 \\
\hline & $(0.06)$ & $(0.06)$ & $(0.06)$ & $(0.05)$ & $(0.06)$ & $(0.05)$ & $(0.06)$ & $(0.05)$ & $(0.06)$ & $(0.05)$ \\
\hline \multirow[t]{2}{*}{ Immigrant parents } & $0.84^{\star \star}$ & $0.89^{\star}$ & $0.85^{\star *}$ & 0.90 & $0.88^{*}$ & 0.92 & $0.85^{\star *}$ & $0.89^{*}$ & $0.86^{\star *}$ & $0.89^{*}$ \\
\hline & $(0.05)$ & $(0.05)$ & $(0.05)$ & $(0.05)$ & $(0.05)$ & $(0.05)$ & $(0.05)$ & $(0.05)$ & $(0.05)$ & $(0.05)$ \\
\hline
\end{tabular}

Notes: Standard errors in parentheses. ${ }^{*} p \leq 0.05,{ }^{\star \star} p \leq 0.01,{ }^{\star \star \star} p \leq 0.001$ (two-tailed tests).All models control for age in 1966.

Table 4 presents results from Gompertz proportional hazards models examining the intersections of adult child attainments and fatherhood. For these models we consider a single measure of adult child attainment with four categories: men without children (17\%); low attainment (14\%), which includes respondents whose highest attaining child has fewer than 12 years of schooling and a manual occupation; high attainment $(23 \%)$, which includes respondents whose highest attaining child has 16 or more years of schooling and a white-collar occupation; and mixed attainment (46\%), which includes respondents whose children have any other combination of educational and occupational attainments. We considered this operationalization of adult child attainment because the analysis stratified by birth cohort suggested that child education had a larger association with the mortality of the younger cohort and child occupation had a larger association with the mortality of the older cohort. Furthermore, educational and occupational attainments often cluster together such that low/high educational attainment leads to low/high occupational attainment. Models 1 through 3 in Table 4 reveal that fathers of high-attaining children have a significantly lower mortality risk than the fathers of low-attaining children and childless men. The difference between mixed and low attainment is also statistically significant $(p<.05)$ in every model.

Table 4: Exponentiated parameter estimates (hazard ratios) from Gompertz proportional hazards models examining the intersections of adult child attainments and fatherhood $(\mathrm{N}=4,938)$

\begin{tabular}{lccc}
\hline & Model 1 & Model 2 & Model 3 \\
\hline Child attainment (ref. no children) & & & \\
Low attainment & $1.19^{*}$ & $1.16^{*}$ & 1.11 \\
& $(0.08)$ & $(0.08)$ & $(0.08)$ \\
Mixed attainment & 0.91 & 0.91 & 0.92 \\
& $(0.05)$ & $(0.05)$ & $(0.05)$ \\
\hline
\end{tabular}


Table 4: (Continued)

\begin{tabular}{|c|c|c|c|}
\hline & Model 1 & Model 2 & Model 3 \\
\hline \multirow[t]{2}{*}{ High attainment } & $0.73^{\star \star *}$ & $0.76^{* * *}$ & $0.80^{* * *}$ \\
\hline & $(0.04)$ & $(0.04)$ & $(0.05)$ \\
\hline \multicolumn{4}{|l|}{ Parent education (ref. 0 to 6 ) } \\
\hline \multirow[t]{2}{*}{7 to 11 years } & & 1.00 & 1.02 \\
\hline & & $(0.04)$ & $(0.04)$ \\
\hline \multirow[t]{2}{*}{12 or more years } & & 0.99 & 1.00 \\
\hline & & $(0.06)$ & $(0.06)$ \\
\hline \multicolumn{4}{|l|}{ Parent occupation (ref. manual) } \\
\hline \multirow[t]{2}{*}{ Skilled labor } & & 0.99 & 1.00 \\
\hline & & $(0.05)$ & $(0.05)$ \\
\hline \multirow[t]{2}{*}{ White-collar } & & 0.98 & 0.99 \\
\hline & & $(0.06)$ & $(0.06)$ \\
\hline \multirow[t]{2}{*}{ Farming } & & $0.87^{\star * *}$ & $0.87^{* \star *}$ \\
\hline & & $(0.03)$ & $(0.04)$ \\
\hline \multicolumn{4}{|l|}{ Personal education (ref. 0 to 11 ) } \\
\hline \multirow[t]{2}{*}{12 years } & & 0.92 & 0.94 \\
\hline & & $(0.04)$ & $(0.04)$ \\
\hline \multirow[t]{2}{*}{13 or more years } & & $0.85^{\star *}$ & $0.87^{*}$ \\
\hline & & $(0.05)$ & $(0.05)$ \\
\hline \multicolumn{4}{|l|}{ Personal occupation (ref. manual) } \\
\hline \multirow[t]{2}{*}{ Skilled labor } & & $0.90^{\star *}$ & 0.94 \\
\hline & & $(0.03)$ & $(0.04)$ \\
\hline \multirow[t]{2}{*}{ White-collar } & & $0.85^{\star *}$ & 0.91 \\
\hline & & $(0.04)$ & $(0.05)$ \\
\hline \multirow[t]{2}{*}{ Farming } & & $0.84^{* *}$ & 0.92 \\
\hline & & $(0.05)$ & $(0.05)$ \\
\hline \multirow[t]{2}{*}{ Log total net worth } & & & $0.96^{* * *}$ \\
\hline & & & $(0.00)$ \\
\hline \multirow[t]{2}{*}{ Divorced, never married, or widowed } & $1.10^{\star \star}$ & $1.09^{*}$ & 1.01 \\
\hline & $(0.04)$ & $(0.04)$ & $(0.04)$ \\
\hline \multirow[t]{2}{*}{ Lived with both parents at 15} & 0.96 & 0.99 & 1.00 \\
\hline & $(0.03)$ & $(0.03)$ & $(0.03)$ \\
\hline \multirow[t]{2}{*}{ Number of children } & $1.04^{\star \star *}$ & $1.04^{* * *}$ & $1.04^{\star * *}$ \\
\hline & $(0.01)$ & $(0.01)$ & $(0.01)$ \\
\hline \multirow[t]{2}{*}{ Number of sons } & $0.92^{\star \star *}$ & $0.91^{\star \star *}$ & $0.92^{* * *}$ \\
\hline & $(0.02)$ & $(0.02)$ & $(0.02)$ \\
\hline \multirow[t]{2}{*}{ Black } & $1.09^{*}$ & 1.02 & 0.93 \\
\hline & $(0.04)$ & $(0.04)$ & $(0.04)$ \\
\hline \multirow[t]{2}{*}{ Immigrant parents } & $0.90^{\star \star}$ & $0.86^{\star \star *}$ & $0.87^{\star \star \star}$ \\
\hline & $(0.03)$ & $(0.03)$ & $(0.03)$ \\
\hline
\end{tabular}

Notes: Standard errors in parentheses. * $p \leq 0.05$, ${ }^{* *} p \leq 0.01,{ }^{* * *} p \leq 0.001$ (two-tailed tests). All models control for age in 1966 Adult children's attainment is defined as follows. The reference category is comprised of older men without children (17\%). Low attainment (14\%) denotes respondents whose highest attaining child has fewer than 12 years of schooling and a manual occupation. High attainment $(23 \%)$ denotes respondents whose highest attaining child has 16 or more years of schooling and a white-collar occupation. Mixed attainment (46\%) denotes respondents whose children include any other combination of educational and occupational attainments. The difference between mixed and low attainment are statistically significant $(p<.05)$ in every model. 


\section{Conclusion and discussion}

In this study we develop and test a new multigenerational model of mortality for older men. Stratification and demographic scholarship on multigenerational processes typically assumes a unidirectional transfer of advantages from older to younger generations within a family. However, the long arm, personal attainment, and social foreground perspectives suggest that mortality disparities in later adulthood are more likely related to adjacent generations. Our results provide evidence of a three-generation model in which parent occupation (G1), personal wealth (G2), and adult child education and occupation (G3) are independently associated with G2 mortality. We discuss these results and their limitations in more detail below.

With respect to parent attainment, only a farming background was consistently associated with mortality. This is likely related to the occupational structure of the early 1900s and the physical advantages of growing up on a farm. The NLS-OM participants were born between 1906 and 1921, which means their families experienced the farming boom of World War I and the Great Depression that followed soon thereafter. Owning or managing a farm during this period was common, and while farmers did not avoid financial problems during the Depression, they were able to grow their own food when malnutrition was widespread (Watkins 2000). Living on farms may have also reduced exposure to the high levels of air pollution in US cities prior to federal policies like the Air Pollution Control Act of 1955. Farming lifestyles are also associated with low rates of childhood obesity and secondhand smoke inhalation, and although the exact biological pathways remain unclear, farming families generally have lower rates of a number of chronic health issues - especially respiratory diseases (Stein et al. 2016) that reduce life chances and increase mortality risk in adulthood (Braveman and Barclay 2009; Palloni et al. 2009).

Adult children's educational and occupational attainments were consistently related to a reduction in mortality risk across models. These findings extend recent research examining the social foreground perspective and highlight the importance of considering the socioeconomic attainments of future generations in models of health and mortality (Friedman and Mare 2014; Torssander 2013, 2014; Yahirun, Sheehan, and Hayward 2016; Zimmer, Hanson, and Smith 2016). We also find evidence that the benefits of fatherhood vis-à-vis mortality were conditional on the attainments of adult children. That is, fathers with high-attaining adult children had an especially low mortality risk when compared to fathers with low-attaining children and men who remained childless.

Models stratified by cohort revealed that the education of adult children had a significantly larger association with the mortality of younger cohorts, whereas the occupation of adult children had a larger association with the mortality of older cohorts. 
This finding reflects other research on the widening education gap in mortality (Meara, Richards, and Cutler 2008; Miech et al. 2011) but also suggests a similar widening may be occurring in the association between adult children's education and parents' health. These cohort differences likely reflect the mid-century shift in the status attainment process from occupation to years of schooling and academic credentials. Given the changing relevance of education for human capital development and labor market outcomes, our findings provide further evidence that the distribution of flexible resources related to health is determined by the broader stratification system within which individuals live (Phelan and Link 2015). These results also lend support to scholarship that conceptualizes educational, occupational, and economic attainments as distinct components of SES, each having its own unique association with health and mortality (Torssander and Erikson 2010; Wolfe 2015).

This study also has notable limitations that provide opportunities for future research. First, we find a robust relationship between the attainment of adjacent generations and the survival of older men, but because results contain several potential threats to causality, they should be interpreted with caution. Although the analysis controlled for average wealth, family structure, and sociodemographic controls, unmeasured confounders could account for the remaining association. Future research should further explore other types of potential confounders and the underlying mechanisms that likely influence the association between multigenerational attainments and mortality, including (1) resources like direct care, financial support, and health spillover provided by adult children; (2) genetic characteristics that determine both academic potential and longevity among family members; (3) personality traits and family cultures that promote achievement and health; and (4) factors like marital stability and social capital that may attenuate the association between adult child attainment and parent health (e.g., the marital histories of parents and adult children, physical distance between family members, and relationship quality).

Related to this, selection into fatherhood is likely playing a role in mortality differences between childless men and fathers who have high-attaining adult children. High-attaining children may very well provide health-related resources, but many of the social, psychological, and physical elements of family formation are also related to early mortality. For example, people with mental health problems like schizophrenia, substance abuse, and depression are less likely to marry, finish high school, and go to college, and have a significantly higher risk of early mortality (Mojtabai et al. 2015, 2017; Walker, McGee, and Druss 2015). Furthermore, gay men may also account for a disproportionate number of men without children, but the NLS does not ask about sexual orientation. Homosexuality was highly stigmatized during the lives of the NLS$\mathrm{OM}$, and the stress of the intense discrimination gay men encountered could help explain differences between the survival of men with and without children (Meyer 
2003). Although these points do not contradict our findings or the social foreground perspective more broadly, they do suggest that future research is necessary to address issues of causality and to elaborate on the interplay of marriage, fertility, socioeconomic attainments, and health across familial generations.

The second limitation concerns economic attainment. The NLS-OM does not contain information on the income or wealth of parents and adult children, and the wealth of adjacent generations may play a more important role in protecting health than educational or occupational attainments. Wealth may also provide a more precise indicator of socioeconomic status, especially for the parents of the NLS-OM participants who were born when education was not as closely tied to status. Thus, examining multigenerational wealth accumulation is an important next step for research on the associations between the attainments of adjacent generations and mortality risk.

The portion of the life course under consideration also has important implications with respect to the relatively weak association between parental attainment and older men's survival. When considered in combination with the extensive literature that has established the association between parents' socioeconomic attainments and childhood health and mortality (Braveman et al. 2010; Case, Lubotsky, and Paxson 2002; Singh and Kogan 2007; Strohschein 2005), our findings suggest the possibility that the relationship between G1, G2, and G3 attainments and G2 mortality is age graded: the sizes of the associations between parent, personal, and adult child attainments and G2 mortality are conditional on the age of G2. In other words, the effects of family attainments on mortality transition from one generation to the next as individuals leave their childhood homes and establish their own families (see Figure 1). However, future research is needed to confirm whether the relatively weak association we find between G1 attainments and G2 mortality is due to an insufficient measure of childhood socioeconomic circumstances or the diminishing association between parents' SES and mortality risk with age (Pudrovska 2014).

Third, the NLS-OM surveys have a number of important characteristics that were necessary to test our model of multigenerational attainment and mortality, but a major limitation of this study is that the analysis does not consider gender or race in more detail. We limit this paper to older men due to the availability of appropriate data and to focus on the baseline effects of multigenerational attainments. Furthermore, although the NLS Mature Women (NLS-MW) contains similar information, these women were 30 to 44 years old in 1967 , substantially younger than the NLS-OM, who were already 45 to 59 in 1966. Thus, extending our findings to address issues related to gender and race is an important next step (Wolfe et al. 2018).

Despite these limitations, our results provide evidence that mortality risk is not only associated with personal attainment but also with the attainments of adjacent generations - both parents and adult children. Identifying the social determinants of 
health disparities is critical for reducing premature morbidity, disability, and death. By 2050 the Census Bureau projects the number of persons aged 65 and older will be 83.7 million (Ortman, Velkoff, and Hogan 2014). This growth presents many challenges for policymakers and federal programs like Social Security and Medicare and for those who provide informal elderly care (Pavalko and Wolfe 2009, 2016a, 2016b). As the United States braces for this dramatic increase in the population of older adults, our findings suggest that social policies aimed at addressing educational inequalities among children and adolescents from disadvantaged families may offer a potential path to reducing health disparities among the elderly. 


\section{References}

Adler, N.E. and Stewart, J. (2010). Health disparties across the lifespan: Meaning, methods, and mechanisms. Annals of the New York Academy of Sciences 1186(1): 5-23. doi:10.1111/j.1749-6632.2009.05337.x.

Almond, D. and Currie, J. (2011). Killing me softly: The fetal origins hypothesis. Journal of Economic Perspectives 25(3): 153-172. doi:10.1257/jep.25.3.153.

Alston, J.M., Andersen, M.A., James, J.S., and Pardey, P.G. (2010). Persistence pays: US agricultural productivity growth and the benefits from public $R \& D$ spending. New York: Springer. doi:10.1007/978-1-4419-0658-8.

Blau, P.M. and Duncan, O.D. (1967). The American occupational structure. New York: Wiley.

Braveman, P.A. and Barclay, C. (2009). Health disparities beginning in childhood: A life-course perspective. Pediatrics 124(Supplement 3): 163-175. doi:10.1542/ peds.2009-1100D.

Braveman, P.A., Cubbin, C., Egerter, S., Williams, D.R., and Pamuk, E. (2010). Socioeconomic disparities in health in the United States: What the patterns tell us. American Journal of Public Health 100(Supplement 1): 186-196. doi:10.1542/peds.2009-1100D.

Case, A., Lubotsky, D., and Paxson, C. (2002). Economic status and health in childhood: The origins of the gradient. The American Economic Review 92(5): 1308-1334. doi:10.1257/000282802762024520.

Chan, T.W. and Boliver, V. (2013). The grandparents effect in social mobility: Evidence from British birth cohort studies. American Sociological Review 78(4): 662-678. doi:10.1177/0003122413489130.

Cherlin, A.J. and Furstenberg, F.F. (1992). The new American grandparent: A place in the family, a life apart. Cambridge: Harvard University Press.

Cohen, S., Janicki-Deverts, D., Chen, E., and Matthews, K.A. (2010). Childhood socioeconomic status, and adult health. Annals of the New York Academy of Sciences 1186(1): 37-55. doi:10.1111/j.1749-6632.2009.05334.x.

Conger, R.D., Conger, K.J., and Martin, M.J. (2010). Socioeconomic status, family processes, and individual development. Journal of Marriage and Family 72(3): 685-704. doi:10.1111/j.1741-3737.2010.00725.x.

Cutler, D.M., Lange, F., Meara, E., Richards-Shubik, S., and Ruhm, C.J. (2011). Rising educational gradients in mortality: The role of behavioral risk factors. Journal of Health Economics 30(6): 1174-1187. doi:10.1016/j.jhealeco.2011.06.009. 
Eddings, W. and Marchenko, Y. (2012). Diagnostics for multiple imputation in stata. Stata Journal 12(2): 353-367.

Elder, G.H. and Conger, R.D. (2000). Children of the land: Adversity and success in rural America. Chicago: The University of Chicago Press.

Evans, G.W. (2004). The environment of childhood poverty. American Psychologist 59(2): 77-92. doi:10.1037/0003-066X.59.2.77.

Evans, G.W. and Kim, P. (2010). Multiple risk exposure as a potential explanatory mechanism for the socioeconomic status. Annals of the New York Academy of Sciences 1186(1): 174-189. doi:10.1111/j.1749-6632.2009.05336.x.

Faris, R.E.L. and Dunham, H.W. (1939). Mental disorders in urban areas: An ecological study of schizophrenia and other psychoses. Chicago: University of Chicago Press.

Friedman, E.M. and Mare, R.D. (2014). The schooling of offspring and the survival of parents. Demography 51(4): 1271-1293. doi:10.1007/s13524-014-0303-z.

Goldin, C. (2003). The human capital century. Education Next 3(1): 73-78.

Goldin, C. and Katz, L.F. (1999). The shaping of higher education: The formative years in the United States. Journal of Economic Perspectives 13(1): 37-62. doi:10.1257/jep.13.1.37.

Graham, J.W., Olchowski, A.E., and Gilreath, T.D. (2007). How many imputations are really needed? Some practical clarifications of multiple imputation theory. Prevention Science 8(3): 206-213. doi:10.1007/s11121-007-0070-9.

Haas, S.A. (2008). Trajectories of functional health: The 'long arm' of childhood health and socioeconomic factors. Social Science and Medicine 66(4): 849-861. doi:10.1016/j.socscimed.2007.11.004.

Hällsten, M. and Pfeffer, F.T. (2017). Family wealth and grandchildren's educational achievement in Sweden. American Sociological Review 82(2): 328-360. doi:10.1177/0003122417695791.

Hayward, M. and Gorman, B.K. (2004). The long arm of childhood: The influence of early-life social conditions on men's mortality. Demography 41: 87-107. doi:10.1353/dem.2004.0005.

Hollingshead, A.B. and Redlich, F.C. (1958). Social class and mental illness: A community study. New York: Wiley. doi:10.1037/10645-000.

Hout, M. (2012). Social and economic returns to college education in the United States. Annual Review of Sociology 38(1): 379-400. doi:10.1146/annurev.soc.012809. 102503. 
Huang, J.Y., Gavin, A.R., Richardson, T.S., Rowhani-Rahbar, A., Siscovick, D.S., and Enquobahrie, D.A. (2015). Are early-life socioeconomic conditions directly related to birth outcomes? Grandmaternal education, grandchild birth weight, and associated bias analyses. American Journal of Epidemiology 182(7): 568578. doi:10.1093/aje/kwv148.

Hummer, R.A. and Lariscy, J.T. (2011). Educational attainment and adult mortality. In: Rogers, R.G. and Crimmins, E.M. (eds.). International handbook of adult mortality. New York: Springer: 241-261.

Jæger, M.M. (2012). The extended family and children's educational success. American Sociological Review 77(6): 903-922. doi:10.1177/0003122412464040.

Kalbfleisch, J.D. and Prentice, R.L. (2011). The statistical analysis of failure time data. New York: Wiley.

Keister, L.A. and Moller, S. (2000). Wealth inequality in the United States. Annual Review of Sociology 26: 63-81. doi:10.1146/annurev.soc.26.1.63.

Kennedy, D.M. (1999). The American people in the great depression: Freedom from fear, part one. New York: Oxford University Press.

Killewald, A., Pfeffer, F.T., and Schachner, J.N. (2017). Wealth inequality and accumulation. Annual Review of Sociology 43: 379-404. doi:10.1146/annurevsoc-060116-053331.

Kwok, M.K., Leung, G.M., Lam, T.H., Leung, S.S.L., and Schooling, C.M. (2013). Grandparental education, parental education, and child height: Evidence from Hong Kong's 'children of 1997' birth cohort. Annals of Epidemiology 23(8): 475-484. doi:10.1016/j.annepidem.2013.05.016.

Lê-Scherban, F., Roux, A.V.D., Li, Y., and Morgenstern, H. (2014). Associations of grandparental schooling with adult grandchildren's health status, smoking, and obesity. American Journal of Epidemiology 180(5): 469-481. doi:10.1093/aje/ kwu154.

Lynch, J.W., Smith, G.D., Kaplan, G.A., and House, J.S. (2000). Income inequality and mortality: Importance to health of individual income, psychosocial environment, or material conditions. BMJ 2000(320): 1200-1204. doi:10.1136/bmj.320.7243. 1200 .

Mare, R.D. (2011). A multigenerational view of inequality. Demography 48(1): 1-23. doi:10.1007/s13524-011-0014-7.

Mare, R.D. (2014). Multigenerational aspects of social stratification: Issues for further research. Research in Social Stratification and Mobility 35: 121-128. doi:10.1016/j.rssm.2014.01.004. 
Masters, R.K., Hummer, R.A., and Powers, D. (2012). Educational differences in US adult mortality: A cohort perspective. American Sociological Review 77: 548572. doi:10.1177/0003122412451019.

Meara, E.R., Richards, S., and Cutler, D.M. (2008). The gap gets bigger: Changes in mortality and life expectancy, by education, 1981-2000. Health Affairs (Millwood) 27(2): 350-360. doi:10.1377/hlthaff.27.2.350.

Meyer, I.H. (2003). Prejudice, social stress, and mental health in lesbian, gay, and bisexual populations: Conceptual issues and research evidence. Psychological Bulletin 129(5): 674-697. doi:10.1037/0033-2909.129.5.674.

Miech, R., Pampel, F., Kim, J., and Rogers, R.G. (2011). The enduring association between education and mortality: The role of widening and narrowing disparities. American Sociological Review 76(6): 913-934. doi:10.1177/0003122 411411276.

Mojtabai, R., Stuart, E.A., Hwang, I., Eaton, W.W., Sampson, N., and Kessler, R.C. (2015). Long-term effects of mental disorders on educational attainment in the national comorbidity survey ten-year follow-up. Social Psychiatry and Psychiatric Epidemiology 50(10): 1577-1591. doi:10.1007/s00127-015-1083-5.

Mojtabai, R., Stuart, E.A., Hwang, I., Eaton, W.W., Sampson, N., and Kessler, R.C. (2017). Long-term effects of mental disorders on marital outcomes in the national comorbidity survey ten-year follow-up. Social Psychiatry and Psychiatric Epidemiology 52(10): 1217-1226. doi:10.1007/s00127-017-1373-1.

Montez, J.K. and Hayward, M.D. (2014). Cumulative childhood adversity, educational attainment, and active life expectancy among US adults. Demography 51(2): 413-435. doi:10.1007/s13524-013-0261-x.

Montez, J.K., Hummer, R.A., Hayward, M.D., and Woo, H. (2011). Trends in the educational gradient of US adult mortality from 1986 through 2006 by race, gender, and age group. Research on Aging 33(2): 145-171. doi:10.1177/016402 7510392388 .

Moore, D.E. and Hayward, M.D. (1990). Occupational careers and mortality of elderly men. Demography 27(1): 31-53. doi:10.2307/2061551.

Ortman, J.M., Velkoff, V.A., and Hogan, H. (2014). An aging nation: The older population in the United States. Washington, D.C.: US Census Bureau (P251140).

Palloni, A., Milesi, C., White, R.G., and Turner, A. (2009). Early childhood health, reproduction of economic inequalities and the persistence of health and mortality differentials. Social Science and Medicine 68(9): 1574-1582. doi:10.1016/ j.socscimed.2009.02.009. 
Pampel, F.C., Krueger, P.M., and Denney, J.T. (2010). Socioeconomic disparities in health behaviors. Annual Review of Sociology 36: 349-370. doi:10.1146/ annurev.soc.012809.102529.

Pappas, G., Queen, S., Hadden, W., and Fisher, G. (1993). The increasing disparity in mortality between socioeconomic groups in the United States, 1960 and 1986. The New England Journal of Medicine 329(2): 103-109. doi:10.1056/NEJM199 307083290207.

Pavalko, E.K. and Wolfe, J.D. (2009). Workplace policies, caregiving, and women's long-term income security. Public Policy and Aging Report 19(1): 27-31. doi:10.1093/ppar/19.2.1.

Pavalko, E.K. and Wolfe, J.D. (2016a). Do women still care? Cohort changes in US women's care for the ill or disabled. Social Forces 94(3): 1359-1384. doi:10.1093/sf/sov101.

Pavalko, E.K. and Wolfe, J.D. (2016b). Unpaid care work. In: Meyer, M.H. and Daniele, E. (eds.). Gerontology: Changes, challenges, and solutions. Santa Barbara: Praeger: 181-203.

Pfeffer, F.T. (2014). Multigenerational approaches to social mobility: A multifaceted research agenda. Research in Social Stratification and Mobility 35: 1-12. doi:10.1016/j.rssm.2014.01.001.

Phelan, J.C. and Link, B.G. (2015). Is racism a fundamental cause of inequalities in health? Annual Review of Sociology 41(1): 311-330. doi:10.1146/annurev-soc073014-112305.

Phelan, J.C., Link, B.G., and Tehranifar, P. (2010). Social conditions as fundamental causes of health inequalities: Theory, evidence, and policy implications. Journal of Health and Social Behavior 51(Supplement 1): 28-40. doi:10.1177/002214 6510383498 .

Preston, S., Heuveline, P., and Guillot, M. (2001). Demography: Measuring and modeling population processes. Malden: Blackwell.

Prix, I. and Pfeffer, F.T. (2017). Does donald need uncle scrooge? Extended family wealth and children's educational attainment in the United States. In: Erola, J. and Kilpi-Jakonen, E. (eds.). Social inequality across generations: The role of compensation and multiplication in resource accumulation. Northampton: Edward Elgar Publishing: 112-135. doi:10.4337/9781786432568.00013.

Pudrovska, T. (2014). Early-life socioeconomic status and mortality at three life course stages: An increasing within-cohort inequality. Journal of Health and Social Behavior 55(2): 181-195. doi:10.1177/0022146514531986. 
Pudrovska, T. and Anikputa, B. (2014). Early-life socioeconomic status and mortality in later life: An integration of four life-course mechanisms. Journals of Gerontology, Series B: Psychological Sciences and Social Sciences 69(3): 451460. doi:10.1093/geronb/gbt122.

Rogers, R.G., Boardman, J.D., Pendergast, P.M., and Lawrence, E.M. (2015). Drinking problems and mortality risk in the United States. Drug Alcohol Dependence 151: 38-46. doi:10.1016/j.drugalcdep.2015.02.039.

Ross, C.E. and Mirowsky, J. (2010). Why education is the key to socioeconomic differentials in health. In: Bird, C.E., Conrad, P., Fremont, A.M., and Timmermans, S. (eds.). Handbook of Medical Sociology. Nashville: Vanderbilt University Press: $33-51$.

Sewell, W.H. (1964). Community of residence and college plans. American Sociological Review 29(1): 24-38. doi:10.2307/2094638.

Sewell, W.H., Haller, A.O., and Ohlendorf, G.W. (1970). The educational and early occupational status attainment process: Replication and revision. American Sociological Review 335(6): 1014-1027. doi:10.2307/2093379.

Sewell, W.H., Haller, A.O., and Portes, A. (1969). The educational and early occupational attainment process. American Sociological Review 34(1): 82-92. doi: $10.2307 / 2092789$.

Singh, G.K. and Kogan, M.D. (2007). Widening socioeconomic disparities in US childhood mortality, 1969-2000. American Journal of Public Health 97(9): 1658-1665. doi:10.2105/AJPH.2006.087320.

Solon, G. (2014). Theoretical models of inequality transmission across multiple generations. Research in Social Stratification and Mobility 35: 13-18. doi:10.1016/j.rssm.2013.09.005.

Song, X. and Mare, R.D. (2017). Short-term and long-term educational mobility of families: A two-sex approach. Demography 54(1): 145-173. doi:10.1007/s13524 -016-0540-4.

Stein, M.M., Hrusch, C.L., Gozdz, J., Igartua, C., Pivniouk, V., Murray, S.E., Ledford, J.G., Marques Dos Santos, M., Anderson, R.L., Metwali, N., Neilson, J.W., Maier, R.M., Gilbert, J.A., Holbreich, M., Thorne, P.S., Martinez, F.D., Von Mutius, E., Vercelli, D., Ober, C., and Sperling, A.I. (2016). Innate immunity and asthma risk in amish and hutterite farm children. New England Journal of Medicine 375(5): 411-421. doi:10.1056/NEJMoa1508749.

Strohschein, L. (2005). Household income histories and child mental health trajectories. Journal of Health and Social Behavior 46(4): 359-375. doi:10.1177/00221465 0504600404 . 
Torche, F. (2011). Is a college degree still the great equalizer? Intergenerational mobility across levels of schooling in the United States. American Journal of Sociology 117(3): 763-807. doi:10.1086/661904.

Torssander, J. (2013). From child to parent? The significance of children's education for their parents' longevity. Demography 50(2): 637-659. doi:10.1007/s13524012-0155-3.

Torssander, J. (2014). Adult children's socioeconomic positions and their parents' mortality: A comparison of education, occupational class, and income. Social Science and Medicine 122: 148-156. doi:10.1016/j.socscimed.2014.10.043.

Torssander, J. and Erikson, R. (2010). Stratification and mortality: A comparison of education, class, status, and income. European Sociological Review 26(4): 465474. doi:10.1093/esr/jcp034.

Umberson, D., Pudrovska, T., and Reczek, C. (2010). Parenthood, childlessness, and well-being: A life course perspective. Journal of Marriage and Family 72(3): 612-629. doi:10.1111/j.1741-3737.2010.00721.x.

Walker, E.R., McGee, R.E., and Druss, B.G. (2015). Mortality in mental disorders and global disease burden implications: A systematic review and meta-analysis. JAMA Psychiatry 72(4): 334-341. doi:10.1001/jamapsychiatry.2014.2502.

Wallace, S. (2012). Social determinants of health inequities and health care in old age. In: Prohaska, T.R., Anderson, L.A., and Binstock, R.H. (eds.). Public health for an aging society. Baltimore: The John Hopkins University Press: 99-118.

Warner, D.F. and Hayward, M.D. (2006). Early-life origins of the race gap in men's mortality. Journal of Health and Social Behavior 47(3): 209-226. doi:10.1177/ 002214650604700302.

Warren, J.R. and Hauser, R.M. (1997). Social stratification across three generations: New evidence from the Wisconsin longitudinal study. American Sociological Review 62(4): 561-572. doi:10.2307/2657426.

Watkins, T.H. (2000). The hungry years: A narrative history of the great depression in America. New York: Henry Holt and Company.

Wolfe, J.D. (2009). Age at first birth and alcohol use. Journal of Health and Social Behavior 50(4): 395-409. doi:10.1177/002214650905000402.

Wolfe, J.D. (2015). The effects of socioeconomic status on child and adolescent physical health: An organization and systematic comparison of measures. Social Indicators Research 123(1): 39-58. doi:10.1007/s11205-014-0733-4. 
Wolfe, J.D., Bauldry, S., Hardy, M.A., and Pavalko, E.K. (2018). Multigenerational attainments, racial inequalities, and the mortality of silent generation women. Journal of Health and Social Behavior 59(3): 335-351. doi:10.1177/00221465 18784596.

Yahirun, J.J., Sheehan, C.M., and Hayward, M.D. (2016). Adult children's education and parents' functional limitations in Mexico. Research on Aging 38(3): 322345. doi:10.1177/0164027515620240.

Zimmer, Z., Hanson, H.A., and Smith, K.R. (2016). Offspring socioeconomic status and parent mortality within a historical population. Demography 53(5): 15831603. doi:10.1007/s13524-016-0502-x. 
Wolfe et al.: Multigenerational socioeconomic attainments and mortality among older men 